\title{
LOYALITAS PETANI DALAM MELAKUKAN PEMBELIAN BENIH PADI PRODUKSI PP KERJA DI SOLO RAYA
}

\author{
Gresia Rahmawati, Mohd. Harisudin, Hanifah Ihsaniyati \\ Program Studi Agribisnis, Fakultas Pertanian, Universitas Sebelas Maret Surakarta \\ Jalan Ir. Sutami No. 36 A Kentingan Surakarta 57126 Telp./Fax (0271) 637457 \\ E-mail: rahmawatigresia@gmail.com
}

\begin{abstract}
The purpose of this research are (1) to know the influence of product quality, price, service quality toward the customer satisfaction PP Kerja and (2) to know the influence of product quality, price, service quality and customer satisfaction toward the PP Kerja's customer loyalty. The research here used explanatory research in this research. The sample used by 50 farmers who are customers of PP Kerja. The sampling technique using Convenience Sampling. Data were collected by questionnaire. The technique of collecting data was solved through observation, interviews and recording. Analysis of the data used is descriptive analysis and path analysis (path analysis). The results of this research showed that (1) the product quality (X1), price (X2) and service quality (X3) simultaneously influenced the customer satisfaction of PP Kerja (Y1). The total influenced of each variabel is 0,339; 0.178 and 0.543. (2) the product quality (X1), price (X2), service quality (X3) and customer satisfaction (Y1) simultaneously influenced the customer loyalty of PP Kerja (Y2). The price variable could influence the total of customer satisfaction 0,222; the service quality variable 0,362 and the customer satisfaction variable 0,442 it could give influence toward the customer satisfaction.
\end{abstract}

Keywords : Price, Customer Satisfaction, Service Quality, Product Quality, Customer Loyalty

\begin{abstract}
Abstrak : Penelitian ini bertujuan untuk (1) mengetahui pengaruh kualitas produk, harga, kualitas pelayanan terhadap kepuasan konsumen PP Kerja dan (2) mengetahui pengaruh kualitas produk, harga, kualitas pelayanan, kepuasan konsumen terhadap loyalitas konsumen PP Kerja. Jenis penelitian yang digunakan adalah explanatory research. Sampel yang digunakan sebesar 50 orang petani yang merupakan pelanggan dari PP Kerja. Teknik pengambilan sampel menggunakan Convenience Sampling. Metode pengumpulan data dengan kuesioner. Teknik pengumpulan data melalui observasi, wawancara dan pencatatan. Analisis data yang digunakan adalah analisis diskriptif dan analisis jalur (path analysis). Hasil penelitian menunjukkan bahwa (1) variabel kualitas produk (X1), harga (X2) dan kualitas pelayanan (X3) secara simultan kualitas produk, kualitas pelayanan dan harga berpengaruh terhadap kepuasan konsumen PP Kerja (Y1). Besarnya pengaruh setiap variabel adalah 0,339; 0,178 dan 0,543. (2) variabel kualitas produk (X1), harga (X2), kualitas pelayanan (X3) dan kepuasan konsumen (Y1) secara simultan berpengaruh terhadap loyalitas konsumen PP Kerja (Y2). Variabel harga dapat mempengaruhi loyalitas konsumen sebesar 0,222; variabel kualitas pelayanan sebesar 0,362 dan variabel kepuasan konsumen sebesar 0,442 dapat mempengaruhi loyalitas konsumen.
\end{abstract}

Kata kunci: Harga, Kepuasan Konsumen, Kualitas Pelayanan, Kualitas Produk, Loyalitas Konsumen 


\section{PENDAHULUAN}

Loyalitas menjadi salah satu prioritas yang harus bisa didapatkan oleh pelaku bisnis. Menurut Griffin dalam Sangadji dan Sopiah (2013) loyalitas merupakan wujud perilaku dari unit-unit pengambilan keputusan untuk melakukan pembelian secara terus menerus terhadap barang dari suatu perusahaan yang dipilih. Menurut Kotler, et al. (2000), perusahaan-perusahaan masa kini berusaha untuk sekuat tenaga mempertahankan pelanggannya. Mereka menyadari bahwa biaya menarik seorang pelanggan baru bisa mencapai lima kali lipat dari biaya mempertahankan seorang pelanggan yang sudah ada. Menurut Griffin (2003), imbalan dari loyalitas bersifat jangka panjang dan kumulatif. Semakin tingginya loyalitas dari pelanggan maka semakin besar laba yang akan diperoleh perusahaan dari pelanggan. Pentingnya loyalitas juga dirasakan oleh pelaku bisnis yang bergerak di bidang pembenihan/ pembibitan yang terjadi saat ini. Produsen benih harus mampu mengetahui dan mencukupi kebutuhan petani, sehingga petani akan melakukan pembelian berulang pada produsen tersebut.

Industri benih dari tahun ke tahun mengalami perkembangan yang cukup pesat. Hal ini karena kebutuhan benih yang terus meningkat sehingga banyak pelaku bisnis yang menggeluti bisnis di bidang ini. Tidak bisa dipungkiri bahwa kebutuhan benih, khususnya benih padi sampai saat ini menuntut harus terpenuhi. Mengingat masyarakat Indonesia sebagian besar mengkonsumsi beras sebagai bahan pangan pokok. Menurut Sudarma (2013), beras merupakan bahan makanan pokok bagi sebagian besar penduduk Indonesia. Meskipun beras dapat digantikan oleh makanan lainnya, namun beras memiliki nilai tersendiri bagi orang yang biasa makan nasi dan tidak dapat dengan mudah digantikan oleh bahan makanan lain. Beras adalah salah satu bahan makanan yang mengandung gizi dan penguat yang cukup bagi tubuh manusia, sebab didalamnya terkandung bahan yang mudah diubah menjadi energi. Menurut Aak (1990), benih padi adalah gabah yang dihasilkan dengan cara dan tujuan khusus untuk disemaikan menjadi pertanaman. Kualitas benih akan ditentukan dalam proses perkembangan dan kemasakan benih, panen dan perontokan, pembersihan, pengeringan, penyimpanan benih sampai fase pertumbuhan di persemaian.

Tercatat sebanyak 82 penangkar benih padi berada di wilayah Solo Raya. Produk benih yang diproduksi oleh setiap penangkar dibawah pengawasan dari BPSB (Balai Pengawasan dan Sertifikasi Benih). Pengawasan yang dilakukan oleh BPSB menerapkan standar yang sama untuk semua penangkar benih padi. Termasuk standar dalam pengawasan kualitas benih padi. Dipergunakannya standar yang sama menjadikan semua penangkar benih memproduksi dengan kualitas yang hamir sama satu dengan yang lain. Adanya kesamaan jenis produk dan standar kualitas produk yang diproduksi setiap penangkar, menyebabkan para penangkar benih berlomba - lomba dalam memasaran produknya kepada petani. Hal tersebut ditambah dengan adanya kemungkinan jumlah penangkar yang semakin bertambah dari waktu ke waktu menyebabkan persaingan bisnis benih padi di Solo Raya juga semakin ketat. Kondisi ini menyebabkan setiap penangkar dituntut mampu memiliki strategi pemasaran yang tepat. Ketepatan strategi tersebut nantinya akan mengarah pada tujuan akhir dari pemasaran yaitu loyalitas konsumen.

PP Kerja merupakan salah satu pelaku penangkar benih padi yang berada di wilayah Solo Raya. PP Kerja sudah memproduksi benih padi selama 43 tahun. Lamanya PP Kerja dapat bertahan dalam dunia perbenihan dengan persaingan yang begitu ketat mengindikasikan bahwa produk PP Kerja menjadi bagian dari pemenuhan kebutuhan petani. Walaupun demikian PP Kerja tetap harus berusaha untuk mempertahankan produknya dari ancaman pesaing. Guna menyikapi fenomena persaingan bisnis perbenihan yang terjadi saat ini, PP Kerja harus mampu membentuk strategi yang tepat melalui produknya. Supaya PP Kerja bisa betahan dan mampu bersaing dengan kompetitor lain. Pembentukan strategi tersebut bisa dianalisis melalui kualitas produk, harga dan kualitas pelayanan PP Kerja saat ini di mata petani.

Penelitian ini fokus pada faktor apa saja yang mempengaruhi loyalitas petani di wilayah Solo Raya yang melakukan pembelian benih padi produksi PP Kerja. Berdasarkan latar belakang tersebut tujuan dalam penelitian ini 
adalah untuk mengetahui pengaruh kualitas produk, harga dan kualitas pelayanan terhadap kepuasan konsumen PP Kerja. Mengetahui pengaruh kualitas produk, harga, kualitas pelayanan dan kepuasan konsumen terhadap loyalitas konsumen PP Kerja.

\section{METODE PENELITIAN}

\section{Metode Dasar Penelitian}

Jenis penelitian yang digunakan adalah explanatory research yaitu penelitian yang bertujuan untuk menguji teori atau hipotesis untuk membuktikan atau menolak teori atau hipotesis yang sudah ada. Penelitian ini dilakukan pada Bulan Mei sampai Juni 2016.

\section{Lokasi/Daerah Penelitian}

Penentuan lokasi penelitian dilakukan dengan sengaja (purposive) yaitu di wilayah Solo Raya yang meliputi 5 kabupaten. Terdiri dari Kabupaten Sragen, Kabupaten Sukoharjo, Kabupaten Wonogiri, Kabupaten Boyolali dan Kabupaten Klaten. Kelima kabupaten tersebut merupakan persebaran produk benih padi produksi PP Kerja di wilayah Solo Raya.

\section{Sampel}

Jumlah sampel yang digunakan dalam penelitian ini berjumlah 50 responden yang terbagi di 5 kabupaten. Metode pengumpulan data menggunakan kuesioner. Teknik pengambilan sampel menggunakan Convenience Sampling. Tabel 1 menunjukkan jumlah sampel di setiap kabupaten.

Tabel 1. Data Pengambilan Sampel

\begin{tabular}{llc}
\hline No. & \multicolumn{1}{c}{ Kabupaten } & Jumlah Responden \\
\hline 1. & Sragen & 14 \\
2. & Wonogiri & 11 \\
3. & Klaten & 10 \\
4. & Boyolali & 10 \\
5. & Sukoharjo & 5 \\
& Total & 50 \\
\hline
\end{tabular}

Sumber : Data Primer

\section{Jenis dan Sumber Data}

Data yang digunakan dalam penelitian ini adalah data primer dan data sekunder. Data primer diperoleh dari penyebaran kuesioner kepada responden. Data sekunder yang digunakan meliputi data internal dan data eksternal. Data internal adalah data sekunder yang sudah tersedia di dalam perusahaan, dalam hal ini adalah PP Kerja. Data eksternal berasal dari berbagai institusi di luar perusahaan. Misalnya buku, jurnal dan sumber lainnya.

\section{Metode Analisis Data}

Analisis data yang digunakan adalah analisis statistik deskriptif dan analisis jalur (path analysis). Menurut Widiyanto (2013), analisis jalur digunakan untuk mengetahui pengaruh langsung dan tidak langsung suatu variabel terhadap variabel lainnya. Menurut Trihendradi (2012), analisis jalur merupakan pengembangan dari analisis regresi yang tidak hanya menguji kelinearan model namun menunjukkan hubungan serta besar pengaruhnya di antara variabel kausal. Diagram jalur hubungan/pola pengaruh antar variabel dalam penelitian ini adalah sebagai berikut.

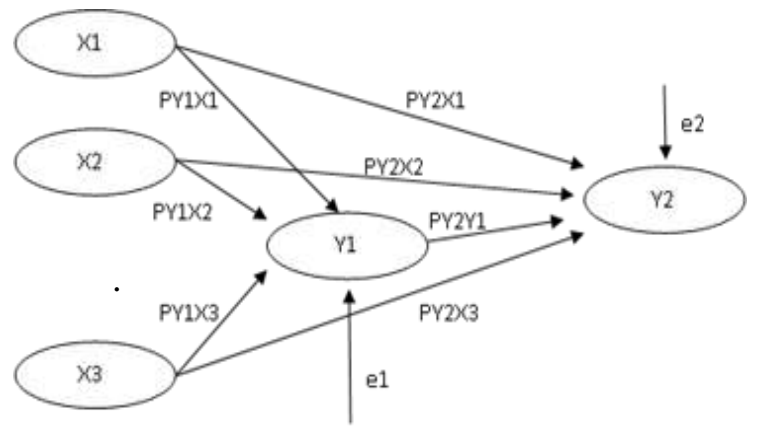

Gambar 1. Diagram Jalur Penelitian

Keterangan :

$\mathrm{X} 1=$ Kualitas produk

$\mathrm{X} 2$ = Harga

$\mathrm{X} 3=$ Kualitas pelayanan

$\mathrm{Y} 1=$ Kepuasan konsumen

Y2 = Loyalitas konsumen

$\mathrm{PY} 1 \mathrm{X} 1=\beta_{1}=$ Koefisien jalur X1 ke Y1

PY1X2 $=\beta_{2}=$ Koefisien jalur X2 ke Y1

$\mathrm{PY} 1 \mathrm{X} 3=\beta_{3}=$ Koefisien jalur X3 ke Y1

$\mathrm{PY} 2 \mathrm{X} 1=\beta_{4}=$ Koefisien jalur X1 ke Y2

PY2X2 $=\beta_{5}=$ Koefisien jalur X2 ke Y2

PY2X3 $=\beta_{6}=$ Koefisien jalur X3 ke Y2

PY1Y2 $=\beta_{7}=$ Koefisien jalur Y1 ke Y2

$\mathrm{e} 1, \mathrm{e} 2=$ error

$\longrightarrow=$ menunjukkan hubungan kausal atau pengaruh langsung dari variabel eksogen (X) terhadap endogen $(\mathrm{Y})$ 
Berdasarkan model diagram jalur tersebut maka dapat dirumuskan persamaan dan hipotesis sebagai berikut :

Model 1

$$
\mathrm{Y}_{1}=\beta_{1} \mathrm{X}_{1}+\beta_{2} \mathrm{X}_{2}+\beta_{3} \mathrm{X}_{3}+\mathrm{e}_{1}
$$

$\mathrm{H} 0=$ Secara simultan kualitas produk, harga dan kualitas pelayanan tidak berpengaruh terhadap kepuasan konsumen

$\mathrm{H} 1$ = Secara simultan kualitas produk, harga dan kualitas pelayanan berpengaruh terhadap kepuasan konsumen

Model 2

$$
Y_{2}=\beta_{4} X_{1}+\beta_{5} X_{2}+\beta_{6} X_{3}+\beta_{7} Y_{1}+e_{2}
$$

$\mathrm{H} 0$ = Secara simultan kualitas produk, harga, kualitas pelayanan dan kepuasan konsumen tidak berpengaruh terhadap loyalitas konsumen

$\mathrm{H} 2$ = Secara simultan kualitas produk, harga, kualitas pelayanan dan kepuasan konsumen berpengaruh terhadap loyalitas konsumen

\section{HASIL DAN PEMBAHASAN}

\section{Profil Produsen Benih Padi PP Kerja}

PP Kerja adalah perusahaan yang bergerak dibidang pembenihan komiditi padi. PP Kerja berlokasi di Dusun Ngemplaksuren, Desa Karangduren, Kecamatan Sawit, Kabupaten Boyolali, Provinsi Jawa Tengah. PP Kerja memiliki visi, misi dan tujuan sebagai perusahaan yang bergerak di bidang pembenihan. PP Kerja sebagai produsen benih memiliki VISI yang berupa "Maju Bersama Petani Menjadi yang Terdepan". MISI PP Kerja sebagai perusahaan swasta murni yang bergerak dalam bidang perbenihan, adalah "Menjadi Perusahaan Swasta Terbesar dalam Industri Benih Padi Nasional".

Produsen benih padi PP Kerja pertama kali didirikan oleh Bp. Soedali (alm). Kurang lebih di tahun 1972. Secara administratif nama PP Kerja terdaftar di BPSB pada tanggal 10 Februari 1982 dengan nomor : 189/BPSBII /Byl/II/82. Sejak tahun 1982 segala kegiatan perbenihan PP Kerja diawasi oleh BPSB Jawa Tengah. Saat ini PP Kerja memproduksi benih padi untuk kelas benih Foundation Seed (FS) dan Stock Seed (SS). Varietas yang dihasilkan meliputi varietas IR.64, varietas Situbagendit, varietas Ciherang, varietas Way Apoburu, varietas Membramo, varietas Inpari 4, varietas Inpari 23, varietas Sidenuk, varietas Bestari, varietas Pepe, dan varietas Sulutan Unsrat 2.

\section{Karakteristik Responden Jenis Kelamin}

Tabel 2. Distribusi Responden Berdasarkan Jenis Kelamin

\begin{tabular}{llcc}
\hline No. & $\begin{array}{l}\text { Jenis } \\
\text { Kelamin }\end{array}$ & Frekuensi & $\begin{array}{l}\text { Persentase } \\
(\%)\end{array}$ \\
\hline 1. & Pria & 47 & 94 \\
2. & Wanita & 3 & 6 \\
& Total & 50 & 100 \\
\hline
\end{tabular}

Sumber : Data Primer

Dilihat dari tabel diatas, pada penelitian ini sebanyak 50 responden sebagai konsumen PP Kerja terdiri dari pria dan wanita. Konsumen pria sebesar 47 orang (94\%) sedangkan sisanya sebanyak 3 orang $(6 \%)$ berjenis kelamin wanita. Data tersebut menunjukkan bahwa konsumen dari PP Kerja sebagian besar adalah petani berjenis kelamin pria.

\section{Usia Responden}

Usia responden dalam penelitian ini tidak dibatasi pada usia tertentu. Respondenresponden ini berada pada kalangan usia yang berbeda - beda. Berikut gambaran usia responden dalam penelitian yang telah dilakukan.

Tabel 3. Distribusi Responden Berdasarkan Usia.

\begin{tabular}{cccc}
\hline No. & $\begin{array}{c}\text { Rentang } \\
\text { Umur }\end{array}$ & Frekuensi & $\begin{array}{c}\text { Persentase } \\
(\%)\end{array}$ \\
\hline 1. & $30-40$ & 8 & 16 \\
2. & $41-50$ & 15 & 30 \\
3. & $51-60$ & 20 & 40 \\
4. & $>60$ & 7 & 14 \\
& Total & 50 & 100 \\
\hline
\end{tabular}

Sumber : Data Primer

Usia merupakan umur dari responden pada saat dilakukan penelitian. Usia tersebut dinyatakan dalam tahun. Karakteristik responden berdasarkan usia menurut tabel diatas, responden sebagian besar berusia antara 51-60 tahun atau sebanyak $40 \%$ dari keseluruhan responden. Responden yang berada pada rentang usia 30 sampai 40 tahun 
sebanyak 8 orang (16\%), kemudian pada usia antara 41 sampai 50 tahun sebesar 15 orang (30\%). Responden yang memiliki usia diatas 60 tahun sebanyak 7 orang.

\section{Lama Penggunaan Benih Padi PP Kerja}

Lama penggunaan produk PP Kerja oleh konsumen berbagai macam. Setiap konsumen satu dengan yang lain tidak selalu sama dalam lama penggunaan produk PP Kerja. Lama penggunaan benih padi PP Kerja oleh responden dapat dilihat pada tabel berikut.

Tabel 4. Distribusi Responden Berdasarkan Lama Penggunaan Produk PP Kerja

\begin{tabular}{clcc}
\hline No & Lama Penggunaan & Jumlah & $\begin{array}{c}\text { Presentase } \\
(\%)\end{array}$ \\
1. & $1-5$ tahun & 27 & 54 \\
2. & $6-10$ tahun & 14 & 28 \\
3. & $11-15$ tahun & 6 & 12 \\
4. & $16-20$ tahun & 2 & 4 \\
5. & $>20$ tahun & 1 & 2 \\
Total & 50 & 100 \\
\hline
\end{tabular}

Sumber : Data Primer

Tabel 4 menjelaskan bahwa lama responden menggunakan produk PP Kerja berkisar antara 1 sampai lebih dari 20 tahun, dimana telah dikelompokkan berdasarkan selang waktu 5 tahun. Reponden yang telah menggunakan produk PP kerja selama 1 sampai 5 tahun sebanyak 27 orang atau $54 \%$, hal ini menunjukkan dalam penelitian ini sebagian besar konsumen yang dijadikan responden banyak yang telah menggunakan produk PP Kerja selama 1 sampai 5 tahun. Sebanyak 14 $(28 \%)$ responden telah menggunakan produk PP Kerja selama 6 sampai 10 tahun. Lama penggunaan pada rentang waktu 11 sampai 15 tahun sebanyak 6 orang (12\%), kemudian pada rentang waktu 16 sampai 20 tahun sebanyak 2 orang responden (4\%) yang telah menngunakan produk PP kerja. Sebanyak 1 orang responden sudah menggunakan produk PP Kerja lebih dari 20 tahun.
Pengaruh Kualitas Produk, Harga, Kualitas Pelayanan terhadap Kepuasan Konsumen

Tabel 5. Hasil Analisis Uji F Persamaan 1

\begin{tabular}{crrr}
\hline Model & F & Sig. \\
\hline Regression & 48,048 &, 000 &
\end{tabular}

Sumber : Analisis Data Primer, 2016

Tabel 5 menunjukkan bahwa tingkat signifikansi variabel kualitas produk, harga dan kualitas pelayanan sebesar $0,000<\alpha=0,05$. Hal ini berarti hipotesis nol (H0) ditolak dan hipotesis 1 (H1) diterima. Artinya secara simultan kualitas produk, kualitas pelayanan dan harga berpengaruh terhadap kepuasan konsumen PP Kerja.

Berdasarkan tabel 6 dapat diketahui persamaan regresinya sebagai berikut :

$Y_{1}=\beta_{1} X_{1}+\beta_{2} X_{2}+\beta_{3} X_{3}+e_{1}$

e1 $=\sqrt{ }\left(\left(1-\mathrm{R}^{\wedge} 2\right)\right)$, kemudian diperoleh nilai e1 sebesar $\sqrt{ }((1-0,758))=0,49$.

$Y_{1}=0,339 X_{1}+0,178 X_{2}+0,543 X_{3}+0,49$

Persamaan tersebut menunjukkan bahwa variabel X1 (kualitas produk) mempunyai pengaruh sebesar 0,339 terhadap kepuasan konsumen dan signifikan pada taraf nyata $5 \%$. Variabel X2 (harga) berpengaruh sebesar 0,178 terhadap variabel kepuasan konsumen. Variabel X3 (kualitas pelayanan) mempunyai pengaruh terhadap kepuasan konsumen sebesar 0,543. Variabel X3 (kualitas pelayanan) adalah variabel yang memiliki pengaruh lebih besar terhadap kepuasan konsumen jika dibanding dengan variabel kualitas produk dan harga.

\section{Pengaruh Kualitas Produk terhadap Kepuasan Konsumen PP Kerja \\ Menurut Kotler dan Amstrong (1997), kualitas produk yaitu kemampuan produk untuk menjalankan tugasnya yang mencakup daya tahan, keandalan atau kemajuan, kekuatan kemudahan dalam pengemasan dan reparasi produk dan ciri-ciri lainnya.}

Tabel 6. Hasil Analisis Uji t Persamaan 1

\begin{tabular}{lcccc}
\hline \multicolumn{1}{c}{ Model } & $\begin{array}{c}\text { Standardized } \\
\text { Coefficients }\end{array}$ & t & Sig. & Keterangan \\
\cline { 2 - 3 } & Beta & & & \\
\hline Kualitas Produk & $\mathbf{3 3 9}$ & 3,188 & 003 & Semua \\
Harga & $\mathbf{1 7 8}$ & 2,419 &, 020 & Variabel \\
Kualitas Pelayanan & $\mathbf{5 4 3}$ & 5,059 &, 000 & Signifikan \\
\hline Sunn
\end{tabular}

Sumber : Analisis Data Primer, 2016 
Kualitas produk PP Kerja dapat mempengaruhi kepuasan konsumen sebesar 0,339. Pengaruhnya lebih kecil dari pada kualitas pelayanan, akan tetapi keberadaan kualitas produk tetap harus selalu diperhatikan dalam mempengaruhi kepuasan konsumen. Jika kualitas produk yang diberikan PP Kerja bagus/baik maka secara langsung konsumen akan merasa puas. Begitu sebaliknya, ketika kualitas produk yang diberikan kepada konsumen tidak sesuai dengan keinginan konsumen maka konsumen akan merasa tidak puas terhadap produk PP Kerja.

Penelitian yang dilakukan oleh Basith, et al (2014), menyimpulkan bahwa pengaruh Kualitas Produk (X1) terhadap Kepuasan Pelanggan (Y1) adalah signifikan. Hasil penelitian tersebut menunjukkan semakin baik kualitas produk yang dihasilkan maka semakin besar perasaan puas yang akan didapat oleh pelanggan. Hal ini berarti bahwa pelanggan dari PP Kerja sudah merasa puas akan produk yang digunakannya, kepuasan pelanggan akan produk tersebut tidak lepas dari upaya PP Kerja sendiri dalam menciptakan benih padi yang berkualitas sesuai dengan harapan konsumen.

\section{Pengaruh Harga terhadap Kepuasan Konsumen PP Kerja}

Konsumen merasa puas karena harga yang ditawarkan oleh PP Kerja sesuai dengan harapan dari konsumen. Selain itu dengan nominal harga yang di tawarkan oleh PP Kerja, konsumen menganggap bahwa harga tersebut masih wajar. Terlebih jika dibanding dengan harga dari produk lain yang sejenis. Menurut McCarthy dan Perreault (1996), harga adalah segala sesuatu atau nilai yang ditetapkan bagi "sesuatu". Sampai saat ini harga benih padi yang ditawarkan oleh PP Kerja adalah sebesar Rp. 48.000,- untuk per pack nya. Setiap pack berisi $5 \mathrm{~kg}$ benih padi. Penelitian ini sejalan dengan penelitian Malik et al. (2012), yang menyatakan bahwa kepuasan dapat secara langsung dipengaruhi oleh faktor harga.

\section{Pengaruh Kualitas Pelayanan terhadap Kepuasan Konsumen PP Kerja \\ Petani sebagai konsumen PP Kerja merasakan kepuasan karena adanya pelayanan yang bagus dari PP Kerja. Hasil penelitian ini sama dengan penelitian yang telah dilakukan oleh}

Sureshchandar et al. (2002), menghasilkan bahwa adanya hubungan antara kepuasan konsumen dengan kualitas pelayanan. Artinya, pelayanan yang diberikan oleh PP Kerja kepada konsumen-konsumennya akan mempengaruhi tingkat kepuasan dari konsumen. Semakin meningkat pelayananyang diberikan PP Kerja maka tingkat kepuasan konsumen juga akan mengalami peningkatan.

Pelayanan yang diberikan PP Kerja kepada petani konsumennya semata-mata adalah wujud perhatian dari PP Kerja kepada petani. Menurut Rahmayanty (2010), pelayanan kepada konsumen dapat memberikan rasa puas dan kepercayaan pada konsumennya. Pelaksanaan pelayanan yaitu berupa pelayanan yang sangat baik dan melampaui harapan konsumen. Adanya pelayanan yang dilakukan oleh perusahaan juga akan berpengaruh pada perasaan pelanggan. Pelanggan merasa diperhatikan dan dipentingkan. Perasaan tersebut akanmembentuk hubungan yang baik antara PP Kerja dengan petani. Hubungan yang terjalin akan memberikan manfaat bagi PP Kerja dalam menjalankan bisnisnya yang akan datang. Besarnya pengaruh pelayanan PP Kerja yang diberikan kepada kepuasan konsumen, dikarenakan pelayanan PP Kerja yang berupa daya tanggap (responsiveness) dan jaminan (assurance) PP Kerja.

\section{Pengaruh Kualitas Produk, Harga, Kualitas Pelayanan dan Kepuasan Konsumen terhadap Loyalitas Konsumen.}

Tabel 7. Hasil Analisis Uji F Persamaan 2

\begin{tabular}{ccc}
\hline Model & F & Sig. \\
\hline Regression & 18,835 & $\mathbf{0 0 0}$ \\
\hline
\end{tabular}

Sumber : Analisis Data Primer, 2016

Tabel diatas menunjukkan bahwa tingkat signifikansi variabel kualitas produk, harga, kualitas pelayanan dan kepuasan konsumen sebesar $0,000<\alpha=0,05$. Hal ini berarti hipotesis nol (H0) ditolak dan hipotesis 2 (H2) pada persamaan kedua diterima. Keempat variabel eksogen tersebut signifikan terhadap loyalitas konsumen. Berdasarkan hasil statistik tersebut maka secara simultan kualitas produk, harga, kualitas pelayanan dan kepuasan konsumen berpengaruh terhdap loyalitas konsumen PP Kerja. 
Tabel 8. Hasil Uji t Persamaan Kedua

\begin{tabular}{lcccc}
\hline \multicolumn{1}{c}{ Model } & $\begin{array}{c}\text { Standardized } \\
\text { Coefficients } \\
\text { Beta }\end{array}$ & $\mathrm{t}$ & Sig. & Keterangan \\
\hline Kualitas Produk &,- 087 &,- 587 &, 560 & Tidak signifikan \\
Harga &, 222 & 2,263 &, 028 & signifikan \\
Kualitas Pelayanan &, 362 & 2,147 &, 037 & signifikan \\
Kepuasan Konsumen &, 442 & 2,388 &, 021 & signifikan \\
\hline
\end{tabular}

Sumber : Analisis Data Primer, 2016

Berdasarkan kedua tabel di atas persamaan kedua dapat dirumuskan sebagai berikut :

$\mathrm{Y}_{2}=\beta_{4} \mathrm{X}_{1}+\beta_{5} \mathrm{X}_{2}+\beta_{6} \mathrm{X}_{3}+\beta_{7} \mathrm{Y}_{1}+\mathrm{e}_{2}$

$\mathrm{e} 2=\sqrt{\left(1-\mathrm{R}^{2}\right)}=\sqrt{(1-0,626)}=0,611$

$\mathrm{Y} 2=-0,087 \mathrm{X} 1+0,222 \mathrm{X} 2+0,362 \mathrm{X} 3+$ $0,442 \mathrm{Y} 1+0,611$

Hasil analisis diatas dengan persamaan tersebut menjelaskan bahwa X1 yaitu kualitas produk tidak berpengruh secara signifikan terhadap variabel Y2 loyalitas konsumen. Loyalitas konsumen pada penelitian ini hanya dipengaruh oleh variabel X2 (harga), X3 (kualitas pelayanan) dan Y1 (kepuasan konsumen). Ketiga variabel eksogen dapat mempengaruhi variabel endogen adalah sebesar 0,222 variabel harga dapat mempengaruhi loyalitas konsumen. Variabel kualitas pelayanan dapat mempengaruhi loyalitas konsumen sebesar 0,362 dan 0,442 variabel kepuasan konsumen dapat mempengaruhi loyalitas dari konsumen.

\section{Pengaruh Kualitas Produk terhadap Loyalitas Konsumen}

Tidak adanya pengaruh kualitas produk PP Kerja terhadap loyalitas konsumen PP Kerja. Hal ini dikarenakan petani sebagai konsumen PP Kerja dalam memutuskan untuk bersikap loyal kepada PP Kerja tidak hanya dipengaruhi oleh kualitas produk benih padi yang diproduksi PP Kerja saja. Petani sudah cukup memahami bahwa kualitas produk yang ditawarkan di pasaran antara produsen satu dengan yang lain hampir sama. Semua produk benih padi yang memiliki sertifikat/berlabel memiliki standar kualitas yang sama.

Tidak banyak perbedaan kualitas benih padi dari merek satu dengan merek lain. Perbedaan terdapat pada lebihnya nilai dari standar yang telah ditentukan. Adanya perbedaan tersebut tidak menunjukkan perbedaan yang signifikan antar benih padi satu dengan yang lain ketika benih telah ditanaman oleh petani. Hasil penelitian ini sejalan dengan penelitian Basith et al. (2014), mengenai pengaruh kualitas produk dan kualitas pelayanan terhadap kepuasan pelanggan dan loyalitas pelanggan (Survei pada Pelanggan De'Pans Pancake and Waffle di Kota Malang) yang menyatakan bahwa kualitas produk tidak secara signifikan mampu mempengaruhi loyalias pelanggan

\section{Pengaruh Harga terhadap Loyalitas Konsumen}

Harga benih padi di pasaran kadang turun kadang naik (tidak stabil). Keadaan ini membuat petani resah dalam mengambil keputusan pembelian benih. Kestabilan harga yang ditetapkan PP Kerja akan membuat petani tidak khawatir dalam membeli produk PP Kerja. Harga cenderung tetap dapat di peroleh oleh petani tanpa harus memikirkan naik turunnya harga secara tiba-tiba. Hal ini juga ditunjang dengan hubungan PP Kerja dengan distributornya.

PP Kerja selalu mengevaluasi dan menghimbau dalam penetapan harga di tempat distributor. Evaluasi dan himbauan harga dilakukan oleh PP Kerja bertujuan untuk tidaknya adanya selisih harga yang sangat tinggi. Harga produk benih padi yang di tetapkan PP Kerja tidak jauh berbeda dengan harga yang ditetapkan distributor. Hasil penelitian ini sejalan dengan penelitian yang telah dilakukan oleh Virvilaite et al. (2009), menerangkan bahwa harga mempengaruhi loyalitas konsumen. Penelitian tersebut juga menyebutkan bahwa harga yang sesuai untuk sebuah produk yang ditawarkan oleh suatu produsen akan berdampak pada adanya kepercayaan yang diberikan oleh konsumen 
Pengaruh Kualitas Pelayanan terhadap Loyalitas Konsumen

Mengacu pada penelitian pada produk yang ditawarkan oleh PP Kerja adalah produk yang menjadi kebutuhan utama petani padi, maka pelayanan yang diberikan PP Kerja dapat mempengaruhi loyalitas konsumennya. Hal ini dikarenakan pelayanan PP Kerja dianggap oleh konsumen sesuai dengan kebutuhan dan keinginanan konsumen. Menurut Tjiptono (2000), pelayanan marupakan sikap dalam melayani pelanggan sehingga pelanggan mendapatkan kepuasan yang meliputi kecepatan, ketepatan, keramahan dan kenyamanan. Saat ini PP Kerja memberikan pelayanan berupa jaminan (assurance) dan daya tanggap (responsiveness) PP Kerja terhadap kebutuhan petani.

Kedua layanan tersebut diberikan kepada PP Kerja dalam bentuk adanya tanggung jawab kepada konsumen apabila produknya tidak sesuai dengan yang dijanjikan (tidak sesuai dengan di label), kondisi produk dalam keadaan baik sampai di tangan konsumen, PP Kerja mampu menyediakan benih secara tepat waktu sesuai kebutuhan petani, varietas yang ditawarkan oleh PP Kerja lebih dari satu jenis misalnya varietas sidenuk, pepe, way apu buru dan lain lain, benih tersedia dalah jumlah yang sesuai dengan kebutuhan/keinginan petani serta mudahnya konsumen mendapatkan produk PP Kerja. Simamora (2003) dalam Sarawati (2014), berpendapat bahwa manfaat kualitas layanan yaitu menciptakan loyalitas pelanggan.

\section{Pengaruh Kepuasan Konsumen terhadap Loyalitas Konsumen}

Oliver (2006) dalam Zulkarnain (2014), menyatakan kepuasan pelanggan adalah perasaan senang atau kecewa yang didapatkan seseorang dari membandingkan antara kinerja (atau hasil) produk yang dipersepsikan dengan ekspektasinya. Artinya, dalam hasil uji statistik penelitian dapat dikatakan bahwa petani yang sudah merasa puas dari produk PP Kerja. Apa yang diharapkan oleh petani sudah mampu dipenuhi oleh PP Kerja. Hal ini akan menciptakan pelanggan yang loyal. Sebagaimana di kuatkan oleh pendapat Sangadji dan Sopiah (2013), bahwa konsumen yang merasa puas pada produk yang dibeli dan digunakannya akan kembali menggunakan produk yang ditawarkan. Menurut Fornell dalam Rosinta dan Aryani (2010), kepuasan pelanggan merupakan kunci dalam menciptakan loyalitas pelanggan.

Tabel 9. Koefisien Jalur, Pengaruh langsung, Pengaruh Tidak Langsung dan Total Pengaruh Kualitas Produk, Harga, Kualitas Pelayanan, Kepuasan Konsumen dan Loyalitas Konsumen

\begin{tabular}{|c|c|c|c|c|c|}
\hline \multirow{2}{*}{ Variabel } & \multirow{2}{*}{$\begin{array}{c}\text { Koefisien } \\
\text { Jalur }\end{array}$} & \multicolumn{3}{|c|}{ Pengaruh } & \multirow{2}{*}{ Keterangan } \\
\hline & & $\mathbf{L S}$ & TLS & Total & \\
\hline $\begin{array}{l}\text { X1 } \\
\text { (Kualitas }\end{array}$ & $-0,087$ & $-0,087$ & $\mathbf{0 , 1 5 0}$ & $\mathbf{0 , 1 5 0}$ & $\begin{array}{l}\text { Secara langsung tidak signifikan dengan loyalitas } \\
\text { konsumen. }\end{array}$ \\
\hline Produk) & & & & & $\begin{array}{l}\text { Kepuasan konsumen Sebagai Variabel } \\
\text { Intervening karena total effect }>\text { direct effect }\end{array}$ \\
\hline X2 (Harga) & 0,222 & 0,222 & 0,078 & 0,3 & $\begin{array}{l}\text { Kepuasan konsumen Sebagai Variabel } \\
\text { Intervening karena total effect }>\text { direct effect }\end{array}$ \\
\hline $\begin{array}{l}\text { X3 (Kualitas } \\
\text { Pelayanan) }\end{array}$ & 0,362 & 0,362 & 0,240 & 0,602 & $\begin{array}{l}\text { Kepuasan konsumen Sebagai Variabel } \\
\text { Intervening karena total effect }>\text { direct effect }\end{array}$ \\
\hline $\begin{array}{l}\text { Y1 } \\
\text { (Kepuasan } \\
\text { Konsumen) }\end{array}$ & 0,442 & 0,442 & - & - & - \\
\hline $\begin{array}{l}\text { Y2 } \\
\text { (Loyalitas } \\
\text { Konsumen) }\end{array}$ & - & - & - & - & - \\
\hline e1 & 0,49 & - & - & - & - \\
\hline $\mathrm{e} 2$ & 0,611 & - & - & - & - \\
\hline
\end{tabular}

Sumber : Data Primer, 2016 


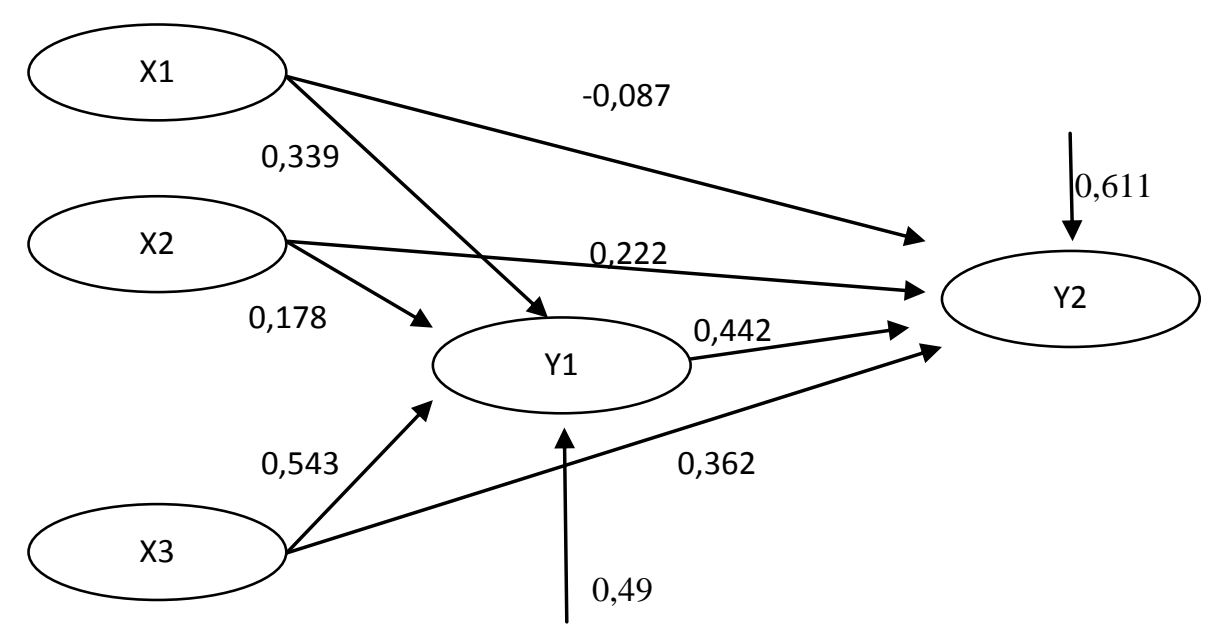

Gambar 2. Hasil Diagram Analisis Jalur dalam Penelitian

\section{Analisis Pengaruh Langsung, Pengaruh Tidak Langsung dan Pengaruh Total}

Berdasarkan kedua persamaan diatas dapat dibadingkan besarnya pengaruh setiap variabel. Hasil uji pengaruh langsung, tidak langsung dan total dapat dilihat pada tabel 9 dibawah ini beserta diagram jalurnya gambar 2. Tabel 9 menunjukkan bahwa pengaruh total lebih besar dibanbing dengan pengaruh langsungnya. Hal ini membuktikkan bahwa variabel kepuasan konsumen sebagai variabel intervening mampu memperkuat variabel eksogen dan endogen.

Tabel 9 menunjukkan bahwa variabel kualitas pelayanan (X3) menjadi fakor dengan pengaruh terbesar yang dapat mempengaruhi variabel loyalitas konsumen (Y2) PP Kerja. Ini terlihat dari jumlah total pengaruh variabel kualitas pelayanan (X3) PP Kerja terhadap variabel loyalitas konsumen (Y2) sebesar 0,602 . Faktor terbesar kedua setelah kualitas pelayanan adalah variabel harga (X2). Harga (X2) PP Kerja dapat mempengaruhi loyalitas konsumen (Y2) PP Kerja dengan total pengaruh sebesar 0,3 . Faktor terakhir yang mempengaruhi loyalitas konsumen (Y2) adalah variabel kualitas produk (X1) PP Kerja. Variabel ini hanya mampu mempengaruhi loyalitas konsumen (Y2) PP Kerja sebesar 0,150 .

\section{KESIMPULAN DAN SARAN}

\section{Kesimpulan}

Kesimpulan dari penelitian ini adalah

1. Variabel kualitas produk (X1), harga (X2) dan kualitas pelayanan (X3) secara simultan signifikan terhadap variabel kepuasan konsumen (Y1). Besarnya pengaruh setiap variabel adalah 0,339; 0,178 dan 0,543 . Kualitas pelayanan (X3) memberikan pengaruh terbesar terhadap kepuasan konsumen (Y1) jika dibanding dengan variabel kualitas produk dan harga.

2. Variabel kualitas produk (X1), harga (X2), kualitas pelayanan (X3) dan kepuasan konsumen (Y1) secara simultan signifikan terhadap variabel loyalitas konsumen (Y2). Namun melalui uji t, kualitas produk (X1) secara individu tidak signifikan terhadap loyalitas konsumen (Y2). Besarnya pengaruh untuk setiap variabel adalah -0,087; 0,222; 0,362 dan 0,442. Kepuasan konsumen (Y1) memiliki pengaruh yang besar terhadap loyalitas konsumen (Y2) jika dibanding dengan variabel lainnya.

\section{Saran}

Saran yang dapat diberikan dari penelitian ini antara lain:

1. Disarankan kepada PP Kerja untuk mempertahankan dan meningkatkan kualitas pelayanan yang ada saat ini. Dilihat dari hasil analisis kualitas pelayanan memberikan pengaruh yang 
besar terhadap kepuasan konsumen sehingga kualitas pelayanan dapat dijadikan strategi utama dalam memberikan kepuasan konsumen. Peningkatan pelayanan dapat berupa selalu terpenuhinya kebutuhan dan keinginan petani mengenai benih padi oleh PP Kerja. Diaharapkan kedepannya petani menjadikan PP Kerja sebagai perusahaan yang dapat diandalkan oleh petani. Tidak hanya itu, PP Kerja juga perlu memperhatikan kualitas produk dan harga produknya sehingga dapat menunjang peningkatan kepuasan konsumen. Cara yang bisa dilakukan yaitu selalu mempertahankan standar mutu benih padi dan melakukan evaluasi harga yang ditawarkan kepada petani.

2. Kepuasan berperan penting dalam menjadikan petani menjadi loyal terhadap PP Kerja, sehingga kepusan petani harus selalu diutamakan. Kepuasan petani dapat tercapai dengan memperhatikan ketiga variabel eksogen yang ada dalam penelitian ini yaitu, kualitas produk, harga dan kualiatas pelayanan. Ketiga variabel tersebut harus mampu memberikan kepuasan kepada petani.

\section{DAFTAR PUSTAKA}

Aak.1990. Budidaya Tanaman Padi. Penerbit Kanisius. Yogyakarta.

Basith, A., S. Kumadji, K. Hidayat. 2014. Pengaruh Kualitas Produk dan Kualitas Pelayanan terhadap Kepuasan Pelanggan dan Loyalitas Pelanggan (Survei pada Pelanggan De'Pans Pancake and Waffle di Kota Malang). Jurnal Administrasi Bisnis, 11 (1): 2-8.

Griffin, J. 2003. Customer Loyalty : How to Earn It, How to Keep It. Alih Bahasa : Dr. Dwi Kartini Yahya. Erlangga. Jakarta.

Kotler, P. dan G. Amstrong. 1997. Prinsipprinsip pemasaran, cetakan pertama. Erlangga. Jakarta.

Kotler, P., S.H. Ang, S.M. Leong, C.T. Tan. 2000. Marketing Management An Asian
Perspective. Diterjemahkan oleh Fandy Tjiptono. Penerbit ANDY and Pearson Education Asia Pte. Ltd.

Litbang. 2016. Rekap data PenangkarBenih PaJaLe di Seluruh Wilayah Indonesia. http://upbs.litbang.pertanian.go.id/assets/ images/penangkar.pdf. Diakses 1 Okober 2016.

Malik, M.E., M.M. Ghafoor, H.K. Iqbal. 2012. Impact of Brand Image, Service Quality and price on customer satisfaction in Pakistan Telecommunication. International Journal of Business and Social Science, 3(23):123-129.

McCarthy, E.J. dan W.D. Perreault. 1996. Dasar-Dasar Pemasaran. Erlangga. Jakarta.

Rahmayanty, N. 2010. Manajemen Pelayanan Prima. Graha Ilmu. Yogyakarta.

Rosinta. F. dan D. Aryani. 2010. Pengaruh Kualitas Layanan terhadap Kepuasan Pelanggan dalam Membentuk Loyalitas Pelanggan. Jurnal Ilmu Administrasi dan Organisasi, 17(2): 114-126.

Sangadji, E.M. dan Sopiah 2013. Perilaku Konsumen Pendekatan Praktis Disertai Himpunan Jurnal Penelitian. Andi. Yogyakarta.

Saraswati, P., S. Kumadji, U. Abdillah. 2014. Pengaruh Kualitas Produk dan Kualitas Pelayanan terhadap Kepuasan dan Loyalitas Pelanggan (Survey Pada Pelanggan Coffee Shop Starbucks Di Surabaya Dan Kuala Lumpur). Jurnal Administrasi Bisnis (JAB), 14 (1): 3 - 7.

Sudarma, I. M . 2013. Penyakit Tanaman Padi (Oryza sativa L). Graha Ilmu. Yogyakarta.

Sureshchandar G.S., R. Chandrasekharan, R.N. Anantharaman. 2002. "The relationship between service quality and customer satisfaction - a factor specific approach". Journal of Services Marketing, 16(4): $363-379$. 
Tjiptono, F. 2000. Manajemen Jasa. Andi. Yogyakarta.

Trihendradi, C. 2012. Step by Step SPSS 20 Analisis Data Statistik. Andi. Yogyakarta.

Virvilaite, R., V. Saladiene, D. Skindaras. 2009. The Relationship between Price and Loyalty in Services Industry. Inzinerine Ekonomika-Engineering Economics(3).
Widiyanto, M. A. 2013. Statistik Terapan : Konsep dan Aplikasi SPSS dalam Penelitian Bidang Pendidikan, Psikologi dan Ilmu Sosial Lainnya. PT. Elex Media. Jakarta.

Zulkarnain. 2014. Entrepreneurial Marketing Teori dan Implementasi. Graha Ilmu. Yogyakarta. 